\title{
Molecular markers linked to the fin gene controlling determinate growth habit in common bean
}

\author{
Astrid Pañeda $\cdot$ Cristina Rodríguez-Suárez $\cdot$ \\ Ana Campa · Juan José Ferreira • \\ Ramón Giraldez
}

Received: 26 June 2007 / Accepted: 5 October 2007

(C) Springer Science+Business Media B.V. 2007

\begin{abstract}
Bulked segregant analysis (BSA) was used to identify molecular markers linked to determinate growth habit ( $f$ in gene) in a $F_{2}$ population derived from the cross Andecha (FinFin) $\times$ BRB130 ( finfin). Fourteen RAPD markers and one microsatellite (BMd45-AIA) were linked to the fin gene when tested on the entire population. The SCAR, SI19b, designed from the RAPD marker OI19 385 (linked to the $f$ in gene at a recombination fraction, $\mathrm{RF}=0.14$; LOD $=5.29$ ), showed a codominant segregation in the $\mathrm{F}_{2}$ population Andecha $\times$ BRB130 consistent with that of the corresponding RAPD. The microsatellite BMd45-AIA showed a codominant segregation in this population and was also linked to the fin gene $(\mathrm{RF}=0.11 ; \mathrm{LOD}=10.73)$. The DNA sequences of markers SI19b and BMd45-AIA present in Andecha and BRB130 were analyzed. The two alleles of marker SI19b differ in 4 single base pairs and in a deletion of $30 \mathrm{bp}$, whereas the two alleles of marker BMd45-AIA differ in a single base pair and in a deletion of $38 \mathrm{bp}$. In both cases, specific short sequences (CTGAAGA for SI19b and ACAGAGAGA for
\end{abstract}

A. Pañeda $\cdot$ C. Rodríguez-Suárez $\cdot$ R. Giraldez $(\bowtie)$ Department of Biología Funcional, University of Oviedo, 33006 Oviedo, Spain e-mail: giraldez@uniovi.es

A. Campa · J. J. Ferreira Area de Cultivos Hortofrutícolas, SERIDA, 33300 Villaviciosa, Asturias, Spain
BMd45-AIA) were repeated at the beginning and the end of the deleted segments, suggesting that "looping" structures during replication could have caused these deletions. Linkage between the fin gene and the molecular markers SI19b and BMd45-AIA was investigated in two other segregating populations: a $\mathrm{F}_{2}$ population derived from the cross MDRK (finfin) $\times$ V225 (FinFin), and a RIL population derived from the cross Xana (finfin) $\times$ Cornell 49242 (FinFin). SI19b was polymorphic (codominant segregation) only in the RIL population Xana $\times$ Cornell 49242, and showed a weak linkage with the fin gene (26.9 cM; LOD = 2.34). BMd45-AIA showed codominant segregation in both populations, and was tightly linked to the fin gene, at $4.1 \mathrm{cM}(\mathrm{LOD}=9.2)$ in the $\mathrm{F}_{2}$ population $\mathrm{MDRK} \times \mathrm{V} 225$, and at $3.3 \mathrm{cM}$ $(\mathrm{LOD}=16.2)$ in the RIL population Xana $\times$ Cornell 49242 .

Keywords Phaseolus vulgaris $\cdot$ Bulked segregant analysis $\cdot$ RAPD $\cdot$ SCAR $\cdot$ Microsatellite $\cdot$ Growth habit

\section{Introduction}

In common bean, the different growth habits have been classified based on the number of nodes, degree and type of branching, internode length, climbing ability and determinate or indeterminate nature (Singh 1982; Debouck and Hidalgo 1985; Van Schoonhoven 
and Pastor-Corrales 1987). Although indeterminate growth habits (vegetative terminal meristem) are associated with higher yields, determinate growth habits (reproductive terminal meristem) are usually preferred because they mature uniformly and quickly, can avoid several diseases, alleviate heat and moisture stress, and permit mechanical harvest (Coyne 1980; Kelly et al. 1987; Myers 1992; Singh 1994; Singh and Muñoz 1999). It has been long recognized that the dominant and recessive alleles of the fin gene condition the indeterminate and determinate growth habits, respectively (Norton 1915; Lamprecht 1935; Coyne and Schuster 1974; Park et al. 1999), and several studies have located this gene on linkage group B1 (Gepts et al. 1993; Koinange et al. 1996; Johnson and Gepts 2002).

The introgression of recessive genes through traditional breeding is laborious and time consuming because of the need for progeny tests to identify the desired genotypes. The need of growing plants till the end of the flowering period to identify their indeterminate or determinate condition represents an added difficulty in the breeding process involving this character. The use of indirect screening methods with molecular markers linked to the fin gene would be of special interest in plant breeding involving the introgression of the determinate growth habit.

Although a RFLP (Gepts et al. 1993) and several RAPDs (Park et al. 1999) have been previously described as markers linked to the fin gene, their use has been limited due to the complexity of the RFLP technique or to a lack of polymorphism and reproducibility of RAPDs across diverse genetic backgrounds and gene pools of common bean. The main objectives of this study were to use the bulked segregant analysis (BSA) with RAPDs and with microsatellite markers previously mapped on linkage group B1, combined with SCAR design, in order to obtain more robust molecular markers linked to the fin gene.

\section{Materials and methods}

Plant material

Three mapping populations representing different gene pools of common bean were used: (i) $\mathrm{F}_{2}$ Andecha $\times$ BRB130 (77 $\mathrm{F}_{2}$ individuals). Andecha is a very large white seeded cultivar of Andean origin, proceeding from a selection of landraces of Asturias (Northern Spain), with an indeterminate growth habit (FinFin). BRB130 is a breeding line of Andean origin [ABA33 $\times$ (ABA $51 \times$ CALIDENT314)] proceeding from CIAT (Cali, Colombia), which presents a determinate growth habit (finfin). This population was used in the bulked segregation analysis (BSA).

(ii) $\mathrm{F}_{2}$ MDRK $\times \mathrm{V} 225\left(50 \mathrm{~F}_{2}\right.$ individuals $)$. MDRK (Michigan Dark Red Kidney) is one of the 12 international anthracnose differential cultivars (Pastor-Corrales 1991) having Andean origin and a determinate growth habit (finfin). V225 is a large white seeded local variety (Asturias) of Middle American origin and having an indeterminate growth habit (FinFin). This population was analyzed with the selected molecular markers in order to confirm their linkage to the fin gene.

(iii) RILs Xana $\times$ Cornell 49242 (102 RILs obtained after seven generations of single seed descent). Xana is a breeding line with a determinate growth habit (finfin) that was derived from the cultivar Andecha (indeterminate) and the local variety V203 (determinate donnor). Cornell 49242 is one of the anthracnose differential cultivars having a Middle American origin and an indeterminate growth habit (FinFin). This population was analyzed with the selected molecular markers in order to confirm their linkage to the fin gene.

The following 26 bean varieties were also analyzed with the selected markers (see Table 2 for Fin/fin genotype and gene pool origin): the remaining ten anthracnose differential cultivars, Michelite, Perry Marrow, Widusa, Kaboon, Mexico222, PI-207262, TO, TU, AB136 and G2333; seven international breeding lines or varieties carrying identified anthracnose resistance genes, A493, A321, A252, SEL1360, SEL1308, Sanilac, and Catrachita; seven bean cultivars or varieties currently grown in Spain, V203, V204, Cimera, Canela, Tolosana, Riñón and Ganxet; and the parent lines of the RIL mapping population in which the common bean integrated map was established (Freyre et al. 1998), BAT93 and Jalo EEP558. 


\section{DNA extraction}

Genomic DNA was isolated from lyophilized young leaves using the Nucleon ${ }^{\mathrm{TM}}$ PhytoPure ${ }^{\mathrm{TM}}$ Genomic DNA Extraction Kit (Amersham Biosciences) following the supplier's instructions.

Bulked segregation analysis (BSA)

BSA bulks were made from the $\mathrm{F}_{2}$ Andecha $\times$ BRB130 population. The genotype of 30 indeterminate $F_{2}$ plants (homozygous or heterozygous) was established through the analysis of the corresponding $\mathrm{F}_{3}$ families (14 plants per $\mathrm{F}_{3}$ family). The primary screening for fin markers was carried out with two DNA bulks prepared from equal volumes of standardized DNA (10 ng/ $\mu \mathrm{l})$ of five homozygote indeterminate plants (FinFin) and five homozygote determinate plants (finfin).

A total of 580 primers obtained from Operon Technologies (Alameda, CA, USA), were screened using the RAPD technique of Williams et al. (1990). PCR amplifications were conducted in a $25 \mu \mathrm{l}$ total reaction mixture containing $30 \mathrm{ng}$ of total DNA, $100 \mathrm{mM}$ Tris-HCl, $100 \mathrm{mM} \mathrm{KCl} \mathrm{pH} \mathrm{8.3,} 4 \mathrm{mM} \mathrm{MgCl}_{2}$, $0.2 \mathrm{mM}$ of each dNTP (Roche), $0.2 \mu \mathrm{M}$ of primer, and 1.25 U Stoffel DNA polymerase (Perkin Elmer). Amplification reactions were performed in a PCR System 9600 (Perkin Elmer) programmed as follows: $94^{\circ} \mathrm{C}$ for $5 \mathrm{~min}, 35$ cycles of $94^{\circ} \mathrm{C}$ for $35 \mathrm{~s}, 40^{\circ} \mathrm{C}$ for $2 \mathrm{~min}$, and $72^{\circ} \mathrm{C}$ for $2 \mathrm{~min}$ with a ramp of $1 \mathrm{~s}$ per cycle, followed by a final step of $72^{\circ} \mathrm{C}$ for $7 \mathrm{~min}$. Size marker from a 100-base pair ladder $\left({ }^{\circ}\right.$ Amersham Biosciences) was used to measure the location of RAPD markers on the agarose gel. Marker size was determined to the nearest 100 base pairs (bp) based on the migration distance in comparison to size markers. The name of each RAPD marker is derived from an ' $O$ ' prefix from Operon primers, the letters identifying the Operon kit, Operon primer number, and the approximate length (bp) of the marker.

The following microsatellites (Yu et al. 1999; Gaitán-Solís et al. 2002; Blair et al. 2003; GuerraSanz 2004), previously located on linkage group B1 (Blair et al. 2003), were also screened: PV-ag003, BM53, BM146, BM157, BM200, BMd10 (identical to PV-ag005), BMd45, and AIA. Microsatellites, BMd45, and AIA, are amplified by different oligonucleotide pairs (developed by Blair et al. 2003 and by Guerra-Sanz 2004, respectively) directed to the same sequence (Genbank entry AF293023). The PCR procedure and electrophoresis analysis was as described by the corresponding authors.

RAPDs and microsatellites showing the appropriate polymorphism between BSA bulks and parents were subsequently tested with individual members of the bulks before testing in the complete population.

SCAR primer design and amplification

After amplification of genomic DNA of BRB130 with primer OI19, the amplified fragment corresponding to RAPD OI19 ${ }_{385}$ was excised and purified by means of the GFX ${ }^{\mathrm{TM}}$ PCR DNA Gel Band Purification Kit ( ${ }^{\odot}$ Amersham Biosciences). The purified DNA fragment was ligated and transformed with the pGEM®-T Easy Vector Systems II kit (Promega, Madison, WI). The cloned RAPD fragment was confirmed by plasmid digestion. Both $5^{\prime}$ and $3^{\prime}$ ends of the cloned fragment was sequenced by means of M13 forward and reverse primers with Perkin Elmer/ Applied Biosystem's AmpliTaq-FS DNA polymerase and Big Dye terminators in an ABI Prism 377 DNA sequencer (Perkin Elmer, Foster City, CA). The DNA sequences of cloned products were analyzed by Chromas version 1.61 (Technelysium Pty Ltd.). On the basis of the sequence of the RAPD product, primer pairs of 20 and 24 bases, respectively, were designed for the specific amplification of the locus identified by RAPD OI19 $9_{385}$. Each primer contained the original 10 bases of the RAPD primer sequence plus the next 10 or 14 internal bases. Care was taken to avoid possible primer dimer or secondary structure formation. Thermocycling parameters for the newly developed SCAR, SI19b, were optimized and the final profile was a single cycle of $2 \mathrm{~min}$ at $95^{\circ} \mathrm{C}, 10 \mathrm{~s}$ at $94^{\circ} \mathrm{C}$ and $1 \mathrm{~min}$ at $72^{\circ} \mathrm{C}$ for 34 cycles, and a final extension for $5 \mathrm{~min}$ at $72^{\circ} \mathrm{C}$. SCAR amplification was performed in a $10 \mu \mathrm{l}$ reaction volume containing the same components used for RAPD analysis, except that the concentration of $\mathrm{MgCl}_{2}$ was $3 \mathrm{mM}$.

\section{Statistical and linkage analysis}

Chi-square was used to test goodness-of -fit of observed to expected ratios in the $\mathrm{F}_{2}$ generation. Linkage analyses were performed using the program MAPMAKER (Lander et al. 1987). The logarithm of 
odds (LOD) score of 3.0 was used as a linkage threshold and distances between markers were presented in centimorgans (cM), as calculated using Kosambi's function by the computer program.

\section{Results and discussion}

The growth habit segregation shown by the $F_{2}$ Andecha $\times$ BRB130 fitted the 3:1 ratio (63 indeterminate versus 14 determinate; $\chi^{2}=1.91 ; P=0.17$ ), supporting the presence of a single gene (Fin,fin) controlling this character in the population.

A total of 580 random primers were screened on the parents and bulks of the Andecha $\times$ BRB130 population. Forty RAPD markers were polymorphic between parents and bulks, and 14 of them were linked to the fin gene when tested on the entire mapping population. Table 1 shows the segregation data, the recombination fraction (RF) and the corresponding LOD, between the fin gene and each one of these 14 RAPD markers. Six of these markers were linked in coupling phase (the parent showing positive amplification of the RAPD carries the dominant indeterminate allele Fin), whereas the remaining eight markers were linked in repulsion phase (the parent showing positive amplification of the RAPD carries the recessive determinate allele fin).
In a marker assisted selection program focused to the introgression of a recessive allele, markers linked in repulsion phase are more efficient. Among the eight RAPD markers linked in repulsion phase with the fin gene, the ones showing the lowest RF (Table 1) were $\mathrm{OD}_{1150} \quad(\mathrm{RF}=0.11 ; \quad \mathrm{LOD}=6.86) \quad$ and $\mathrm{OI} 19_{385}$ $(\mathrm{RF}=0.14$; $\mathrm{LOD}=5.29)$, the size of the DNA fragment corresponding to RAPD marker OI19 ${ }_{385}(385$ bp) being more suitable for their transformation into a SCAR. This band was purified, cloned, sequenced, and the SCAR SI19b primers 5'-AATGCGGGAGG AAAGAAAAAAGGT-3' and 5' ${ }^{\prime}$-AATGCGGGAG CGGAAAAGTT-3' were designed (the sequence corresponding to the RAPD is underlined). These primers amplified a single DNA fragment of $414 \mathrm{bp}$ in Andecha, and a single DNA fragment of $384 \mathrm{bp}$ in BRB130 (see below). The SCAR SI19b had a codominant segregation in the Andecha $\times$ BRB130 population that was consistent with the dominant segregation shown by RAPD OI19 385 .

The microsatellites PV-ag003, BM53, BM146, BM157, BM200, BMd10 and BMd45, previously located on linkage group B1 by Blair et al. (2003), and the microsatellite AIA (directed to the same sequence of BMd45; Guerra-Sanz 2004), were also screened on the parents and bulks of the Andecha $\times$ BRB130 population. PV-ag003, BM53, and BMd10, were not polymorphic between the parents Andecha
Table 1 Linkage analysis between plant growth habit (fin gene) and 14 RAPD markers obtained after BSA in the $\mathrm{F}_{2}$ population Andecha $\times$ BRB130
+ and - indicate presence or absence of amplification of the corresponding RAPD fragment, respectively. Linkage values are expressed as RF (recombination fraction) and LOD

\begin{tabular}{|c|c|c|c|c|c|c|c|c|}
\hline \multirow[t]{3}{*}{ Markers } & \multicolumn{2}{|c|}{ Parental genotypes } & \multicolumn{4}{|c|}{$\mathrm{F}_{2}$ plant phenotypes } & \multicolumn{2}{|c|}{ Linkage } \\
\hline & \multirow{2}{*}{$\begin{array}{l}\text { Andecha } \\
\text { FinFin }\end{array}$} & \multirow{2}{*}{$\begin{array}{l}\text { BRB130 } \\
\text { finfin }\end{array}$} & \multicolumn{2}{|c|}{ Fin - } & \multicolumn{2}{|c|}{ Finfin } & \multirow[t]{2}{*}{$\mathrm{RF}$} & \multirow[t]{2}{*}{ LOD } \\
\hline & & & + & - & + & - & & \\
\hline $\mathrm{OZ} 10_{800}$ & + & - & 50 & 1 & 4 & 9 & 0.10 & 6.69 \\
\hline $\mathrm{OW}_{900}$ & + & - & 56 & 2 & 6 & 7 & 0.15 & 4.68 \\
\hline $\mathrm{OI}_{200}$ & + & - & 55 & 3 & 5 & 8 & 0.14 & 5.24 \\
\hline OL20 $0_{775}$ & + & - & 52 & 1 & 5 & 8 & 0.11 & 5.75 \\
\hline $\mathrm{OK} 4_{875}$ & + & - & 53 & 1 & 6 & 7 & 0.13 & 5.04 \\
\hline $\mathrm{OD} 3_{700}$ & + & - & 40 & 0 & 4 & 6 & 0.10 & 4.69 \\
\hline OI19 385 & - & + & 33 & 25 & 12 & 1 & 0.14 & 5.29 \\
\hline $\mathrm{OF} 2_{375}$ & - & + & 31 & 26 & 11 & 2 & 0.22 & 3.40 \\
\hline $\mathrm{OA} 4_{1100}$ & - & + & 29 & 21 & 9 & 2 & 0.18 & 3.68 \\
\hline $\mathrm{OV}_{675}$ & - & + & 32 & 23 & 12 & 2 & 0.20 & 3.62 \\
\hline OR15 150 & - & + & 20 & 28 & 11 & 2 & 0.17 & 5.20 \\
\hline $\mathrm{OO}_{10} 0_{350}$ & - & + & 29 & 23 & 11 & 1 & 0.17 & 4.22 \\
\hline OJ15 500 & - & + & 25 & 31 & 10 & 3 & 0.24 & 3.41 \\
\hline OD8 $8_{1150}$ & - & + & 19 & 27 & 11 & 1 & 0.11 & 6.86 \\
\hline
\end{tabular}


and BRB130. Microsatellites BM146, BM157, and BM200, were polymorphic between the parental lines, but no positive results were found when analyzed in the bulks. Amplification of the microsatellites, BMd45, and AIA, under the conditions described by the authors, was very poor. As indicated previously, microsatellites BMd45 and AIA are amplified by different primer pairs (developed by Blair et al. 2003, and by Guerra-Sanz 2004, respectively) directed to the same sequence (Genbank entry AF293023). Therefore, we tried to improve the amplification quality by combining those primers. The combination (BMd45-AIA) of the forward primer for BMd45 (5'-GGTTGGGAAGCCTCATA CAG- $\left.3^{\prime}\right)$ and the reverse primer for AIA (5'-TAGTC CTTGCTTTCTTTTGC-3') amplified a single DNA fragment of $245 \mathrm{bp}$ in Andecha and a single DNA fragment of $207 \mathrm{bp}$ in BRB130 (see below). This polymorphism could be unequivocally identified through agarose gel electrophoresis and was positive in the bulks. When analyzed in the entire Andecha $\times$ BRB130 population, BMd45-AIA had a codominant segregation and was linked to the fin gene at a distance of $10.7 \mathrm{cM}(\mathrm{RF}=10.5 \% ; \mathrm{LOD}=$ 10.73).

The amplification products of markers SI19b and BMd45-AIA obtained from Andecha and BRB130 were purified, cloned and sequenced. Figure 1 shows the comparison between these sequences. The two alleles of marker SI19b differ in 4 single base pairs and in a deletion of $30 \mathrm{bp}$, whereas the two alleles of marker BMd45-AIA differ in a single base pair and in a deletion of $38 \mathrm{bp}$. In both cases, specific short sequences (CTGAAGA for SI19b and ACAGAGAGA for BMd45-AIA) were repeated at the beginning and the end of the deleted segments. This suggests that "looping" structures during replication could have caused these deletions.

The segregation of markers SI19b and BMd45AIA was also analyzed in the $\mathrm{F}_{2}$ of MDRK $\times$ V225, and in the RILs Xana $\times$ Cornell 49242, two populations in which the fin gene was also segregating. SI19b was polymorphic (codominant segregation) only in the RILs Xana $\times$ Cornell 49242 population, and showed a weak linkage with the fin gene $(26.9 \mathrm{cM} ; \mathrm{RF}=24.6 \% ; \mathrm{LOD}=2.34) . \quad \mathrm{BMd} 45-\mathrm{AIA}$
Fig. 1 Sequence alignment of the SI19b and BMd45AIA fragments cloned from Andecha and BRB130.

Single nucleotide polymorphisms (arrows) and short sequences (boxes) repeated at the beginning and the end of the deleted segments are indicated

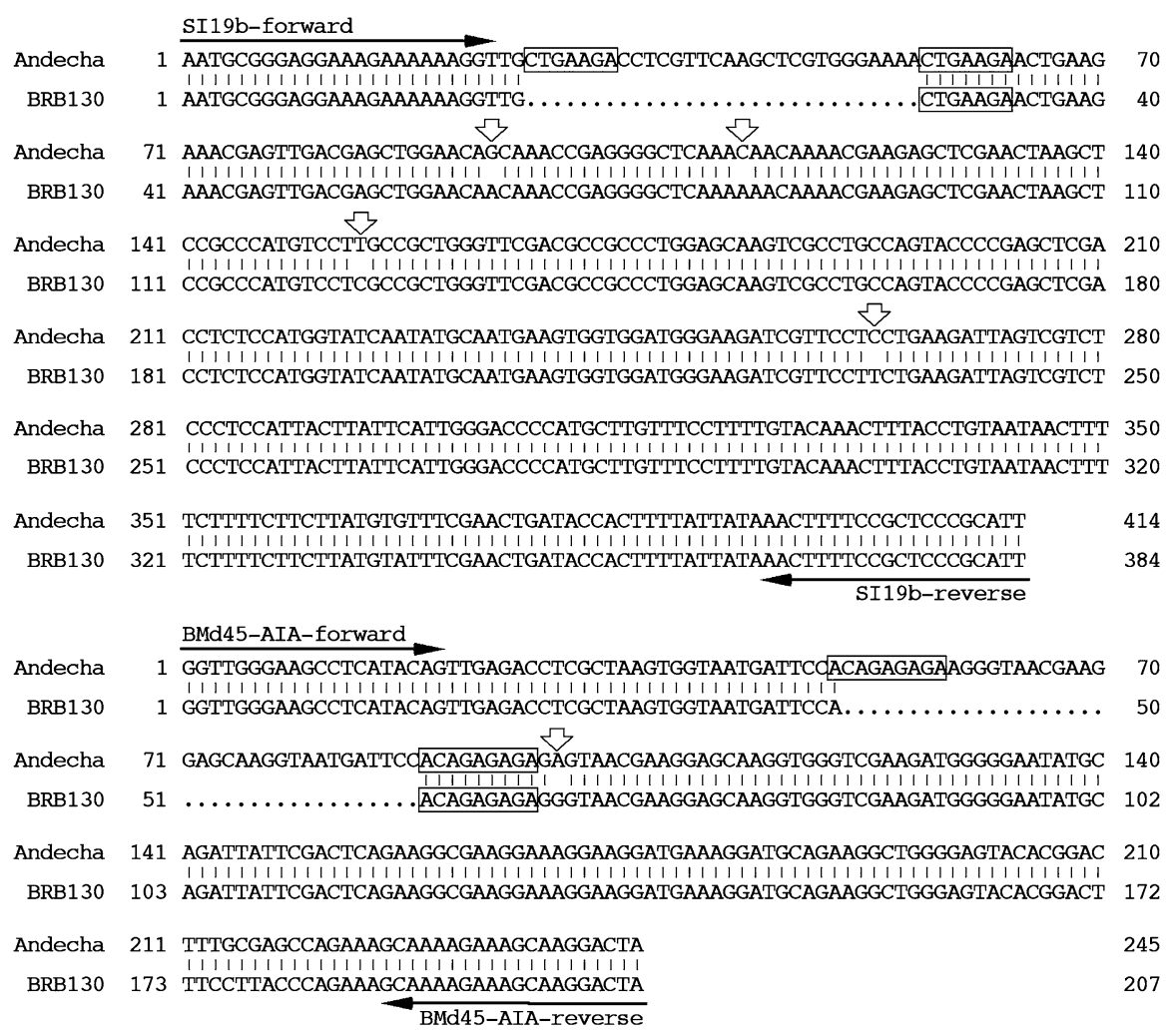


showed codominant segregation in both populations, mapping at $4.1 \mathrm{cM}(\mathrm{RF}=4.1 \%$; $\mathrm{LOD}=9.2)$ from the fin gene in the MDRK $\times \mathrm{V} 225$ population, and at $3.3 \mathrm{cM}(\mathrm{RF}=3.3 \%$; LOD $=16.2)$ from the fin gene in the Xana $\times$ Cornell 49242 population.

The linkage found between the BMd45-AIA microsatellite and the fin gene is in agreement with previous reports for the placement of these two loci. Blair et al. (2003), using the recombinant inbred line population DOR $364 \times$ G19833, mapped the BMd45 microsatellite in a distal position on linkage group B1. Later, Blair et al. (2006), using an advanced backcross inbred line population created from ICA Cerinza (determinate growth habit) crossed with G24404 (indeterminate growth habit), mapped the fin gene in an equivalent position on B1.

The genotype for markers SI19b and BMd45-AIA was investigated to determine their usefulness in different Middle American and Andean common bean cultivars or lines (Table 2). Most Middle American cultivars/lines, irrespective of their growth habit, carry the alleles $\mathrm{SI}_{19 b_{414}}$, and BMd45-AIA 207 , the alleles $\mathrm{SI}_{19 \mathrm{~b}_{385} \text {, and BMd45-AIA }}$, , being present only in the determinate cultivar Mexico 222. On the contrary, nine
Table 2 Common bean cultivars/lines characterized according to their origin, growth habit, and size of the amplification product of molecular markers SI19b, and BMd45-AIA

\begin{tabular}{|c|c|c|c|c|}
\hline Cultivar/line & Origin & Growth habit & SI19b & BMd45-AIA \\
\hline Xana & Andean & Determinate & 385 & 245 \\
\hline Kaboon & Andean & Determinate & 385 & 245 \\
\hline V203 & Andean & Determinate & 385 & 245 \\
\hline V204 & Andean & Determinate & 385 & 245 \\
\hline Canela & Andean & Determinate & 385 & 245 \\
\hline BRB130 & Andean & Determinate & 385 & 245 \\
\hline MDRK & Andean & Determinate & 414 & 245 \\
\hline Jalo EEP558 & Andean & Indeterminate & 385 & 245 \\
\hline Perry Marrow & Andean & Indeterminate & 385 & 245 \\
\hline Riñón & Andean & Indeterminate & 385 & 245 \\
\hline Tolosana & Andean & Indeterminate & 385 & 207 \\
\hline Andecha & Andean & Indeterminate & 414 & 207 \\
\hline Cimera & Andean & Indeterminate & 414 & 207 \\
\hline Mexico 222 & Middle American & Determinate & 385 & 245 \\
\hline Sanilac & Middle American & Determinate & 414 & 207 \\
\hline Widusa & Middle American & Determinate & 414 & 207 \\
\hline TO & Middle American & Determinate & 414 & 207 \\
\hline A 252 & Middle American & Indeterminate & 414 & 207 \\
\hline Cornell 49242 & Middle American & Indeterminate & 414 & 207 \\
\hline ВАТ93 & Middle American & Indeterminate & 414 & 207 \\
\hline A321 & Middle American & Indeterminate & 414 & 207 \\
\hline A493 & Middle American & Indeterminate & 414 & 207 \\
\hline Catrachita & Middle American & Indeterminate & 414 & 207 \\
\hline Michelite & Middle American & Indeterminate & 414 & 207 \\
\hline PI 207262 & Middle American & Indeterminate & 414 & 207 \\
\hline TU & Middle American & Indeterminate & 414 & 207 \\
\hline AB136 & Middle American & Indeterminate & 414 & 207 \\
\hline G2333 & Middle American & Indeterminate & 414 & 207 \\
\hline SEL1360 & Middle American & Indeterminate & 414 & 207 \\
\hline SEL1308 & Middle American & Indeterminate & 414 & 207 \\
\hline V225 & Middle American & Indeterminate & 414 & 207 \\
\hline Ganxet & Middle American & Indeterminate & 414 & 207 \\
\hline
\end{tabular}




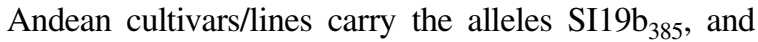
BMd45-AIA $_{245}$, the four cultivars MDRK, Tolosana, Andecha and Cimera showing different allele combinations. From these results, an association of the marker alleles with the gene pool origin rather than with the Fin/fin alleles could be deduced. This association could be explained under the assumption of an independent and fairly recent origin of determinate growth habits in Middle American and Andean bean materials.

Even though the linkage distances between the markers and the fin gene are probably not tight enough to ensure a tagging with no recombinants, the markers can be useful for MAS in the introgression of the determinate growth habit, particularly in breeding programs involving Andean bean cultivars in which a greater variation in the different allele combinations is present. Among the materials shown in Table 2, an example of how the growth habit and the two markers SI19b and BMd45-AIA are transmitted together can be found. Andecha is a very valuable indeterminate, large white seeded cultivar originating from a selection of landraces of Asturias (Spain), and V203 is a local variety having determinate growth habit. Xana is a breeding line having a seed phenotype similar to Andecha and a determinate growth habit proceeding from V203. This breeding line was obtained from the cross Andecha $\times$ V203, followed by a selection during seven generations of selfing. Xana obtained the alleles $\mathrm{SI}_{19 b_{385} \text {, and BMd45-AIA }}$,45, together with the fin allele from V203.

Acknowledgements This work was supported by grants AGL2001-2676-CO2 and RTA02-052-C2 from the Ministerio de Ciencia y Tecnología, Spain. Astrid Pañeda was recipient of a salary fellowship from the Fundación para el Fomento de la Investigación Científica y Tecnológica (FICYT), Principado de Asturias, Spain. Cristina Rodríguez-Suárez was recipient of a salary fellowship from the Ministerio de Ciencia y Tecnología, Spain. Ana Campa was recipient of a salary fellowship from the Instituto Nacional de Investigación y Tecnología Agraria y Alimentaria (INIA, Spain).

\section{References}

Blair MW, Pedraza F, Buendia HF, Gaitán-Solís E, Beebe SE, Gepts P, Tohme J (2003) Development of a genome-wide anchored microsatellite map for common bean (Phaseolus vulgaris L.). Theor Appl Genet 107:1362-1374

Blair MW, Iriarte G, Beebe S (2006) QTL analysis of yield traits in an advanced backcross population derived from a cultivated Andean x wild common bean (Phaseolus vulgaris L.) cross. Theor Appl Genet 112:1149-1163
Coyne DP (1980) Modification of plant architecture and crop yield by breeding. Hortscience 15:244-247

Coyne DP, Schuster ML (1974) Inheritance and linkage relations of reaction to Xanthomonas phaseoli (E.F. Smith) Dowson (common blight), stage of plant development and plant habit in Phaseolus vulgaris L. Euphytica 23:195-204

Debouck DG, Hidalgo R (1985) Morfología de la planta del fríjol común. En: Fríjol: investigación y producción. CIAT, Cali, Colombia, pp 7-4

Freyre R, Skorch PW, Geffroy V, Adam-Blondon A-F, Shirmohamadali A, Johnson WC, Llaca V, Nodari RO, Pereira PA, Tsai SM, Tohme J, Dron M, Nienhuis J, Vallejos CE, Gepts P (1998) Towards an integrated linkage map of common bean IV. Development of a core linkage map and alignment of RFLP maps. Theor Appl Genet 97:847-856

Gaitán-Solís E, Duque MC, Edwards KJ, Tohme J (2002) Microsatellite repeats in common bean (Phaseolus vulgaris L.): isolation, characterization, and cross-species amplification in Phaseolus spp. Crop Sci 42:2128-2136

Gepts P, Nodari R, Tsai SM, Koinange EMK, Llaca V, Gilbertson R, Guzman P (1993) Linkage mapping in common bean. Annu Rep Bean Improv Coop 36:24-38

Guerra-Sanz JM (2004) New SSR markers of Phaseolus vulgaris from sequence databases. Plant Breed 123:87-89

Johnson WC, Gepts P (2002) The role of epistasis in controlling seed yield and other agronomic traits in an andean $x$ mesoamerican cross of common bean (Phaseolus vulgaris L.). Euphytica 125:69-79

Kelly JD, Adams MW, Varner GV (1987) Yield stability of determinate and indeterminate dry bean cultivars. Theor Appl Genet 74:516-521

Koinange EMK, Singh SP, Gepts P (1996) Genetic control to the domestication syndrome in common bean. Crop Sci 36:1037-1045

Lander ES, Green P, Abrahamson J, Barlow A, Daly MJ, Lincon SE, Newburgh L (1987) MAPMAKER: an interactive computing package for constructing primary genetic linkage maps of experimental and natural population. Genomics $1: 174-181$

Lamprecht H (1935) Zur genetic von Phaseolus vulgaris. X. Über Infloreszenztypen und ihre Vererbung. Hereditas 20:71-93

Myers JR (1992) Values and use of the National Dry Bean Nurseries. Annu Rep Bean Improv Coop 35:1-2

Norton JB (1915) Inherance of habit in the common bean. Am Nat 49:547-561

Park SO, Coyne DP, Bokosi JM, Steadman JR (1999) Molecular markers linked to genes for specific rust resistance and indeterminate growth habit in common bean. Euphytica 105:133-141

Pastor-Corrales MA (1991) Estandarización de variedades diferenciales y designación de razas de Colletotrichum lindemuthianum. Phytopathology 81:694

Singh SP (1982) A key for identification of different growth habits of Phaseolus vulgaris L. Annu Rep Bean Improv Coop 25:92-94

Singh SP (1994) Gamete selection for simultaneous improvement of multiple traits in common bean. Crop Sci 34:352-355

Singh SP, Muñoz CG (1999) Resistance to common bacterial blight among Phaseolus species and common bean improvement. Crop Sci 39:80-89 
Van Schoonhoven A, Pastor-Corrales MA (1987) Standard system for the evaluation of bean germplasm. CIAT, Cali, Colombia

Williams JGK, Kubelik AR, Livak KJ, Rafalski JA, Tingey SV (1990) DNA polymorphism amplified by arbitrary primers are used as genetic markers. Nucleic Acids Res 18:65316535

Yu K, Park SJ, Poysa V (1999) Abundance and variation of microsatellite DNA sequences in beans (Phaseolus and Vigna). Genome 42:27-34 